\title{
DA RELAÇÃO ENTRE LINGUAGEM E SUBJETIVIDADE NA OBRA TARDIA DE MARTIN HEIDEGGER
}

\section{Maurício Fernando Pitta}

\begin{abstract}
RESUMO
Este artigo centra-se na relação problemática entre subjetividade e linguagem; mais especificamente, na possibilidade ou impossibilidade de alguma forma de prioridade semântica do sujeito em sua relação com a linguagem quando posta diante dos principais escritos sobre linguagem na filosofia tardia de Martin Heidegger, com enfoque na conferência $O$ caminho para a linguagem, de 1959. Para a modernidade, a linguagem é expressão da atividade interior do espírito. Tal concepção é apontada e criticada por Heidegger sua conferência, na qual afirma, em oposição a ela, que a linguagem, mais do que expressão subjetiva, é o caminho no qual o homem, "ente dizente", já sempre se encontra de início. Neste trabalho, introduziremos, primeiramente, alguns pressupostos heideggerianos de sua obra posterior à fase de Ser e tempo e conceitos característicos dessa etapa, tais como Ereignis, alétheia e tópos, a fim de articular, ao fim, sua concepção tardia de linguagem e contrapô-la à concepção técnica de linguagem, própria da modernidade.
\end{abstract}

Palavras-chave: Linguagem. Ontologia. Subjetividade. Técnica. Topologia.

\begin{abstract}
This paper focus on the problematic relation between subjectivity and language; more specifically, on the possibility or impossibility of some sort of subject's semantical priority in relation to language next to Martin Heidegger's main texts on language from his later works, with emphasis in $A$ way to language (1959). Modernity represents language as expression of mind's inner activity. Such a conception is pointed out and criticized by Heidegger in his conference, in which he claims, opposingly, language is, more than subjective expression, the way in which man, "saying being", already finds himself from the beginning. Firstly, in this work, one introduce some of the Heideggerian assumptions in his work posteriously from Being and time and proper concepts of this stage, such as Ereignis, aletheia, and topos, in order to articulate, at the end, his later notion of language and put it against the technical and modern notion of language.
\end{abstract}

Keywords: Language. Ontology. Subjectivity. Technology. Topology.

\footnotetext{
$\overline{1}$ Doutorando em Filosofia pela Universidade Federal do Paraná e Mestre em Filosofia pela Universidade Estadual de Londrina.
} 


\section{Introdução}

Neste trabalho' ${ }^{2}$, pretendemos pôr em questão, no escopo da filosofia $\operatorname{tardia}^{3}$ de Heidegger, a relação entre linguagem e subjetividade ou, em específico, a possibilidade de determinação semântica da linguagem a partir da subjetividade do sujeito falante, característica essa cara à filosofia da representação moderna e que influenciou inúmeras reflexões filosóficas posteriores sobre epistemologia, linguagem e comunicação. Para ser mais preciso, o que se põe em questão se clarifica quando perguntamos se há possibilidade de determinar o sentido da linguagem a partir das categorias da subjetividade se levados em consideração os principais pressupostos da obra tardia heideggeriana sobre verdade, lugar e linguagem. Ao tão logo anteciparmos que a linguagem, na concepção heideggeriana, se dá como lugar de manifestação do ser, tópos que precede o homem e doa sentido ao seu mundo, evidenciamos já a hipótese inicial de que o sentido da linguagem não tem sua determinação no sujeito que fala e, dessa forma, que a noção moderna de subjetividade contrapõe-se aos pressupostos tardios da filosofia de Heidegger.

Para lidar com a problemática de nosso artigo, dividimos este em duas partes: na primeira seção, exploraremos as características gerais e os pressupostos principais do pensamento tardio de Heidegger para, na segunda, reduzirmos o escopo da exposição para a noção de linguagem e para a discussão desenvolvida em $O$ caminho para a linguagem. Intentamos, com isso, explicitar a compreensão de Heidegger sobre a linguagem ela mesma, conduzindo às considerações finais em resposta à devida questão: há possibilidade de criação e determinação de sentido da linguagem a partir tão somente da subjetividade do sujeito que fala se a linguagem, ela mesma, for pensada já de início em sua relação fundamental com o lugar(tópos)?

\footnotetext{
${ }^{2}$ Este trabalho surgiu como continuação, aprimoramento e aprofundamento das discussões tratadas no artigo publicado pela Filogênese da UNESP de Marília sob o título Humboldt e Heidegger sobre linguagem: expressão do espírito ou morada do ser? (PITTA, 2014, p. 108-120).

3 Por "tardia", compreendemos a filosofia de Heidegger em seus escritos a partir da Kehre do decorrer da década de 30, mas com ênfase acima de tudo em seus textos sobre linguagem da década de 50 .
} 


\section{O pensamento tardio de Martin Heidegger}

Toda a obra de Heidegger se guia pelo mesmo problema: a questão do ser (die Seinsfrage). Não é possível compreender a questão do ser se nos ativermos, segundo o pensador alemão, à concepção corrente de ser (Sein), que professa sua quididade (quidditas), ou seja, o que o ser "é" - enquanto conceito de maior extensão e menor compreensão, como termo mais autoevidente e menos compreensível (HEIDEGGER, 2012, p. 2-5). É preciso ficar clara a diferença: tudo aquilo que é se denomina ente (Seiende), ou seja, algo do qual se pode atribuir ser. Pressupõe-se erroneamente, já diria o filósofo em Ser e tempo, o ser como um ente entre outros - ou ainda, o ser como "essência" (essentia) do ente, sua substância última (ibid. p. 4). A essentia do ente é, ela mesma, um ente predicável, enquanto substância atual e sempre presente do ente. A pressuposição de partida do ser como ente ("o ser é...”) está contida, como base de toda ontologia, naquilo que Heidegger chamou de esquecimento do ser (Seinsvergessenheit), e que caracteriza a cultura ocidental, bem como sua tradição filosófica e científica, como metafísica ontoteológica (id. 2006, p. 66): o ser já é, na colocação de sua questão mais elementar, "o que é ser?", pressuposto como um ente (enquanto ser do ente, fundamentando qualquer ontologia substancial, e enquanto ente primordial, causa de todos os entes, fundamentando qualquer teologia). Sendo assim, toda ontologia histórica enquanto tal, fundada no ser enquanto partícula ontológica e linguística (ainda que nem sempre manifesta no discurso) que sempre dá sentido e medida aos entes em geral, se pauta no obscurecimento da diferença do ser para com o ente na pressuposição do ser enquanto um ente, o que implica na perda da questionabilidade do próprio ser (cf. MALPAS, 2006, p. 44), que já vem explicado e pressuposto e que não precisa mais ser pensado para que se possa falar, atuar no mundo, construir filosofia, arte e ciência.

Para Heidegger, deve-se escapar à tentação de pressupor um fundamento inconcusso do real, que recai invariavelmente na suposição de que, por trás de tudo, encontra-se uma causa ôntica primeira, isto é, um ente primordial. Questionar o ser implica o próprio "pôr em questão" da diferença enquanto tal no seu abismo (Abgrund), isto é, na própria retração do ser, em 
sua condição de possibilidade, a qualquer presentação, cognoscibilidade e redução explicativa, pois no desvelar do ente, seu horizonte de sentido e de possibilidade sempre se retrai (cf. CASANOVA, 2012, p. 166). O real não se funda em uma causa motriz última, mas sim na retração e no mistério (Geheimnis), constitutivos e, por isso mesmo, inescrutáveis à explicação humana. Isso significa dizer que o fundo do real encontra-se no próprio "sem fundo", isto é, na própria abissalidade de um não-fundamento - um fundamento que não é nada de ente e, por isso, que não se dá como fundamento no sentido ordinário (cf. HEIDEGGER, 2006, p. 41). Fundamento como nulidade constitutiva: abismo. A questão do ser e a diferença ontológica implicam, portanto, no reconhecimento dos limites do conhecimento epistemológico e, mais ainda, nos limites de possibilidade da ontologia.

Heidegger, para quem o pensamento, sobretudo na obra tardia, não deve almejar explanação e análise, mas evocação e experiência, busca pensar a maneira pela qual a tradição opera com a substancialização do ser, a fim de experienciar (erfahren) o acontecimento do ser em sua doação primordial. O filósofo, portanto, remonta à Grécia, berço da questão primeira do ser pelos primeiros metafísicos e, portanto, ponto de partida da tradição ocidental. O passo de Heidegger é um passo de retorno, viragem (Kehre), que busca não a essência enquanto quididade (essentia), mas a essência enquanto origem primordial (Wesen) que, na sua manifestação primeira, originária, fornece medida ao mundo histórico subsequente (cf. MALPAS, 2006, p. 267). Deve-se buscar, portanto, o tópos, o lugar (Ort) de manifestação primeira da questionabilidade do ser para, com isso, se pôr em posição de experienciar, novamente, a própria situação do ente na totalidade do início da tradição metafísica, com os gregos, para que se abra possibilidade de recomeço (ibid. p. 221). Questionar é remontar ao lugar de origem. Por isso, a questionabilidade do ser implica na situadidade (Befindlichkeit) ${ }^{4}$ do humano

\footnotetext{
${ }^{4}$ Traduzimos Befindlichkeit, normalmente traduzido por "encontrar-se", "estado de ânimo" ou "disposição", pelo neologismo "situadidade", baseados, sobretudo, na leitura de Malpas (situatedness, "situadidade"; cf. MALPAS, 2006) e Franck (sentiment de la situation, "sentimento da situação"; cf. FRANCK, 2007) do termo. Em alemão, sich befinden pode ser traduzido literalmente como "situar-se", e befindlich é adjetivo que indica situação, como, por exemplo, em "am Rand befindlich", "marginal" ou, mais literalmente, "situado na margem"; logo, Befindlichkeit indicaria o ser-situado, ou seja, em um movimento ortográfico compreensível, embora neologístico, "situadidade".
} 
no lugar do ser e, portanto, é dessa forma que Heidegger pode dizer que a questão do ser é uma questão de ordem estritamente topológica.

Não se deve compreender "lugar" aqui, noção pressuposta no conceito de situadidade, como um espaço geograficamente localizado e delimitado - como se Heidegger buscasse, em uma área restrita entre tais e tais coordenadas geográficas que delimita o território grego, ou como se buscasse, na reunião, em um tópico logicamente ordenado, de artefatos e obras de arte homéricas e pré-homéricas, um conjunto de causas responsáveis pelo descarrilar da metafísica. Lugar deve ser compreendido para o filósofo alemão, já de início, em sua correlação com a noção de acontecimento, Ereig$n i s^{5}$. Novamente, tal acontecimento não é um acontecimento entre outros os primeiros Jogos Olímpicos, a Guerra de Peloponeso etc. —, mas é o acontecimento primordial de abertura de dada ontologia, enquanto doação e retração primeira do ser nos entes, não simplesmente localizável em uma sistematização específica de historiografia por não ser um elemento ou o conjunto de elementos motrizes de determinada data. Tal acontecimento congrega ser, que dá a medida e a tonalidade de uma dada ontologia, e humano, como testemunha e participante desse acontecimento, com seu ser doado pela destinação do próprio ser (cf. HEIDEGGER, 2006, p. 45). Heidegger remonta até onde lhe é acessível: aos pensadores pré-socráticos, não como causadores dos entes, e sim no seu ainda não efetuar da pergunta diretriz da metafísica, orientando-se pré-teoricamente no mundo por noções ontológicas que, aparentemente inacessíveis aos homens na contemporaneidade tecnológica, abriram caminho para a questão, fazendo-os, portanto, participantes do acontecimento primordial do ser (ibid. p. 14-15).

\footnotetext{
${ }^{5} \mathrm{O}$ termo Ereignis, conforme apontado na tradução de Casanova, possui uma tripla conotação, oriunda dos termos alemães Augen (olhos) e Eigen (próprio), além do uso comum do termo no alemão cotidiano como "acontecimento", "evento". Para Casanova, o que se busca pensar no uso desse termo em meio ao texto heideggeriano - no caso, Contribuições à filosofia: do Ereignis (HEIDEGGER, 1989) — é "um acontecimento no interior do qual tem lugar por meio da experiência da visão uma determinada apropriação [...] por parte do homem de si mesmo enquanto ser-aí, na medida mesmo em que o ser-aí se deixa apropriar pelo ser, pela história do ser, pela verdade do ser." (CASANOVA in HEIDEGGER, 2015, p. 6) Nessa citação, "ser-aí" (Dasein) identifica já um povo histórico humano na situação ontológica aberta pelo Ereignis. Em virtude da variedade de traduções ("acontecimento apropriativo", "acontecimento apropriador", "acaecimento propicio", "event", "l'événement", "enowning" etc.) e por sua dificuldade, optamos por utilizar, aqui e doravante, o termo original em alemão, "Ereignis".
} 
No cerne dessas noções, residia a noção primordial de alétheia. Esse termo designou o que a tradição latina concebeu por veritas (em alemão, “Wahrheit"; em português, "verdade") como adæquatio rei et intellectus (cf. AQUINO, 2002, p. 149), adequação ou conformidade de uma proposição com relação à coisa predicada. Contudo, Heidegger sinaliza outro sentido para o termo, mais primordialmente grego (cf. 1976, p. 201): desencobrimento (Unverbogenheit). O que isso diz à primeira vista é que o ente deve primeiramente estar descoberto, presente, antes de se tornar passível de enunciação e de verdade e falsidade, no sentido lógico aristotélico dos termos. Em sentido ontológico, isso significa que ele deve ter já um ser antes de poder servir de sujeito lógico da proposição. Mas, em sentido mais originário, alétheia é a-létheia, des-encobrimento, como a dinâmica mesma de retração do ser como horizonte de possibilidade da qual, como origem e vigência (Anwesenheit), se manifestam os entes em sua dinâmica de descobrimento e encobrimento. Portanto, a alétheia vem como revelação a partir do abscôndito do ser, e a conotação da letra alfa, que se tornou privativa apenas no pensamento grego tardio, ainda mantém concatenação e dependência mútua do revelado com o próprio velamento e retração característicos da léthe, do esquecimento ou encobrimento. O ser se doa aos entes como alétheia, ou seja, como retração na abertura de um mundo (HEIDEGGER, 2000, p. 267).

Contudo, a partir de Platão, no início do questionamento efetivo sobre o ser, cambiou-se o sentido de alétheia, priorizando-se o lado descoberto da dinâmica e, com isso, extraviando-se a retração do ser e a dinâmica do devir a favor de sua substancialização no que o filósofo grego chamou de idéa ou eîdos, a forma ou o aspecto sempre presente do ente enquanto tal. A busca platônica passou a ser a busca pela suma idéa, causa primordial de todo o real. Aristóteles, por outro lado, criticou a transcendência platônica a favor de um, para Heidegger, não menos metafísico realismo: ser, de idéa suprassensível, tornou-se ousía, substantivo derivado do feminino do particípio presente do verbo "ser" grego, einai, como congelamento da dinâmica da alétheia no presente constante da substância subjacente à multiplicidade de modos de ser do ente (cf. HEIDEGGER, 2006, p. 15-16). De todos os modos de dizer o ente, o mais fundamental passou a ser sua "atualidade", 
sua enérgeia, enquanto presença constante do ente, ou enquanto finalidade mesma daquilo que tem a potencialidade, dýnamis, de ainda atualizar sua essentia, e o fundamental na manifestação do mundo passou a ser a predicação de acidentes ao ente atualizado como hypokeímenon, isto é, como substrato lógico essencial (no latim: subjectum, aquilo que subjaz). Sobre esses passos, a teologia cristã e a subjetividade moderna desenvolveram declinações desse acontecimento primordial rumo ao predomínio da técnica moderna (cf. HEIDEGGER, 2000, p. 72-73), da qual abordaremos na seção seguinte, e que, segundo Heidegger, é, enquanto acontecimento do ser, o "negativo fotográfico" (HEIDEGGER, 1986, p. 366, trad. nossa) do Ereignis originário.

A preocupação que subjaz à questão do ser enquanto questionabilidade de sua diferença e sua retração com relação ao ente, bem como de seu caráter de fundamentação histórica e abissal de toda e qualquer ontologia, é, de acordo com Malpas (cf. 2006, p. 221), uma preocupação pelo modo como se configura a confluência entre a unidade do mundo reunido e sua diferença com relação à coisa, assim como das coisas entre si. Por isso, tal preocupação é uma preocupação com o lugar que sustenta o jogo de unidade e diferença, bem como de mútua dependência, de mundo e coisa; é uma preocupação com o caráter de ser-situado do humano em sua relação com o ser - a situadidade do humano que habita o tópos, a casa do ser (cf. ibid. p. 60). É necessário, contudo, que sejam explicitados, com ênfase própria, os dois planos em jogo quando se fala no "jogo topológico [topological play]" (MALPAS, 2006, p. 221, trad. nossa) entre unidade e diferença, bem como entre ser e humano: mundo e coisa. Aqui, deve ficar claro que, ao se falar de lugar em Heidegger, a relação que devemos ter em vista é a do acontecimento de mundo e coisa em conjunto, no qual um não faz sentido sem que, imediatamente, já se tenha o outro no horizonte, como em um jogo de figura e fundo, no qual, ao focar o primeiro plano, o segundo não desaparece, mas apenas perde o foco, e vice-versa. Isto implica dizer que a coisa, mesmo que pareça estar sozinha, sempre reúne um mundo, e o mundo, mesmo que pareça ser apenas totalidade, é sempre uma reunião de coisas.

Por um lado, mundo (Welt) não surge, no pensamento heideggeriano, como "tudo que é o caso", um amontoado de entes e estados de coisa, ou 
espaço aberto, formal e sem qualidades que pode abarcar coisas dentro de si - seja enquanto extensionabilidade vazia real ou enquanto projeção do sujeito do conhecimento. Mundo, enquanto horizonte de possibilidade do ente, nem mesmo pode ser predicado (cf. HEIDEGGER, 2000, p. 181). O "mundo" apenas "mundifica" (Welt weltet) (id. 1977, p. 30, trad. nossa); em outras palavras, mundo se dá como mundo, assim como ser acontece como ser. O mundo, para Heidegger, "mundifica" enquanto abertura do lugar para presentação do real em todas as suas dimensões: na retração da terra inescrutável, na expansão do céu sem fundo, na vida e morte de mulheres e homens e na celebração e contemplação da tradição e do sagrado que antecede e permeia os mortais. Na reunião desses quatro polos, encontra-se o acontecimento do mundo enquanto quadratura (Geviert), concepção influenciada pela poesia de Friedrich Hölderlin, que para Heidegger é o poeta por excelência, em sentido primordial. "Nomeamos o acontecente jogo-de-espelhos [ereignende Spiegel-Spiel] da simplicidade de terra [Erde] e céu [Himmel], mortais [Sterblichen] e imortais [Göttlichen] de mundo." (HEIDEGGER, 2000, p. 181, trad. e grifos nossos) A imagem do mundo enquanto jogo [Spiel], a mesma que menciona Malpas (cf. 2006, p. 242), evoca a mútua dependência, em sua dinâmica de unidade e diferença, entre os quatro polos, que tem seu ser sempre a partir da reunião simples do mundo. Esses quatro polos congregam o cruzamento entre o aberto do espaço na alétheia e o acontecimento do tempo e da história no Ereignis, dimensões mutuamente implicadas e que, inseridas no jogo do mundo, se espelham e se complementam na unidade do lugar (cf. ibid. p. 256).

Coisa (Ding), por outro lado, em muito difere do objeto (Gegenstand), que é uma representação que o sujeito opõe, objeta, diante de si ( $o b$ jectum), como ocorre com a "coisa" extensa (res cogitans) cartesiana uma ideia que tem substancialidade apenas a partir da prova do eu pensante (res extensa). Também “a coisa coisifica” (das Ding dingt) (HEIDEGGER, 2000, p. 179, trad. nossa), ou seja, se dá como coisa, independente de que um sujeito a represente, de forma ativa. A coisa também não se confunde com ente, que pode se dizer de várias formas (objeto, instrumento, Deus, humano, animal etc.), embora possa ser entificada e até representada, de forma derivativa - como pode o mundo, quando concebido como totalidade 
de entes e instrumento de exploração. A coisa, primordialmente, "coisifica" ao reunir ${ }^{6}$ a quadratura do mundo na abertura de um lugar em que a coisa vige, realizando, nessa reunião, a diferença com relação a outras coisas ao instaurar um lugar próprio. Uma ponte congrega as margens, amparada sobre a firmeza da terra, mas também serve para o caminhar do mortal, exposta aos céus e devedora de uma história que remonta ao imemorial, ao sacro. Ou melhor: a ponte ocupa uma extensão, mas também aproxima e distancia os homens, que a habitam enquanto transeuntes de tal e tal maneira, em dado momento e em correlação com a história da própria ponte, com as condições historiográficas necessárias para sua construção, com os causos que dela são contados ao longo do tempo, e assim por diante. Da mesma forma ocorre com a caneca de café, a araucária na rua, os óculos que tenho sobre a face, a colina que, de períodos jurássicos, erigiu-se na paisagem... As coisas, congregando os quatro polos, também se diferenciam entre si por sua singularidade no tempo e espaço (tanto em sentido primordial, enquanto demora ou estância que dá sentido ao lugar aberto na vigência da coisa e que a torna referência enquanto cruzamento de polos e ponto de reunião, como em sentido derivado, como pontos vazios e abstratos no tempo-espaço da Física).

Mundo e coisa se dão juntos, reunidos nos quatro polos da quadratura, no acontecimento do lugar, no "aí" do ser (Da-sein), em que o humano, mortal, se vê situado e no qual seu ser está em jogo como aquele que, projetado constantemente às próprias possibilidades, antevê a própria morte como possibilidade somente sua e por isso questiona o ser de sua finitude, bem como o ser em geral (cf. HEIDEGGER, 2000, p. 180-181). Por isso, é como mortal que o humano habita o lugar. O habita na proximidade (Nähe) com as coisas, nas quais os entes vêm de encontro em seu ser, mais primordialmente do que na sua simples disposição como objetos disponíveis para um sujeito. O humano não está geometricamente ao lado de objetos simplesmente - e o habitar não implica uma simples proximidade físico-matemáti-

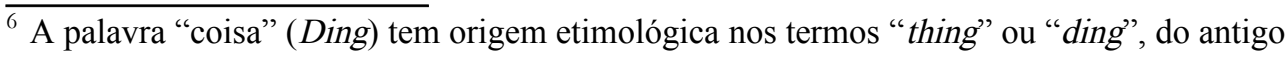
alto-alemão, que remetem ao sentido de "reunião convocada, para tratar de um assunto em questão, de um assunto em disputa." (HEIDEGGER, 2000b, p. 176, trad. nossa) Da mesma forma ocorre com o latim causa, do qual nossos termos "coisa" e "causa" são derivados, enquanto uma congregação para tratar de um assunto em comum. Assim, o "coisar" ou "coisificar" teria também o sentido de "reunir" e "por em questão", "por em causa".
} 
ca: a mulher que habita em outra cidade pode estar mais próxima do ente amado que a anseia em seu íntimo de que o anônimo transeunte na rua com quem ele distraidamente cruza; o texto que se lê, em seu sentido, está mais próximo do leitor do que os tipos impressos que codificam a mensagem ou do que as lentes em contato direto com sua córnea.

Os entes já possuem sentido para o humano, que dele são próximos, familiares, habituais, e esse sentido está em implicação com a finitude constitutiva do humano, em que seu ser está, nas possibilidades abertas com o trato com cada coisa, constantemente em jogo para seu ser como seu mais inalienável horizonte de sentido. Animais e coisas, perecíveis organicamente, não têm, para Heidegger, o mundo como os mortais (Sterblichen) o têm, pois não experimentam a morte como morte ( $T o d$ als $T o d)$, isto é, não a têm no horizonte como possibilidade vislumbrada e sempre, sub-repticiamente, presente (cf. ibid. p. 180). No caso dos animais, "pobres de mundo" (id. 1992, p. 284, trad. nossa), eles não morrem (sterben) constantemente, tendo a morte como limite sempre presente, no horizonte da consciência, mas apenas findam (verenden) (cf. HEIDEGGER, 2000, p. 180), e por isso seu mundo, quando muito, não adquire a abertura do mundo do ser, mas se mantém restrito a algo até certo ponto semelhante a um "mundo ambiente" (Umwelt) ou um habitat específico. Por isso, não ocupam o polo dos mortais, em seu papel de guarda e testemunha do acontecimento do ser, por manterem com ele relação assinalada, mas apenas participam do acontecimento do ser como coisas em geral, com todas as implicações que o conceito pressupõe.

Os mortais, enquanto povo histórico, por outro lado, habitam como clareira (Lichtung) do ser, na qual a coisa mesma vigora sobre a terra, sob o céu e exposta à luz do divino, e na qual se dá o acontecimento do lugar. É nesse habitar - também, como exposto em Construir, habitar, pensar (HEIDEGGER, 2000), um “construir" (bauen), enquanto "cultivar" (pflegen, colere, cultura), deixar o ente ser em sua própria manifestação, e "edificar" (errichten, ædificare), semelhante ao grego poíesis, isto é, produzir enquanto dar condições para que o ente venha à tona em seu ser) (cf ibid. p. 149, trad. nossa) - que se traz à luz e se preserva os entes e o mundo em sua unidade, diferença e mútua dependência, preservando o ser dos entes em sua retração e seus limites. 
Se esse habitar é habitar o lugar de proveniência, como demorar-se na própria casa (Heimat), Heidegger vê no humano moderno um desalojado (Heimatlos), alguém que vive na errância, no desalojamento (Heimatlosigkeit), sem senso do mistério (Geheimnis) do sagrado (Heilige) de seu lugar próprio, de sua tradição, e que se desnorteou e se desnorteia constantemente do caminho (Weg) de sua essência (Wesen), de sua origem (cf. HEIDEGGER, 2000, p. 163-164). Por isso, é necessário a salvação (Heilen), o retorno ao lar (Heimkehre), à terra natal (Heimat), ao lugar, enquanto uma reorientação de mundo (ou uma reorientação ao mundo, em seu sentido mais fundamental) (cf. ibid. p. 186). Mas, se o esquecimento não é fruto do humano e se, ecoando Hölderlin (cf. 1991, p. 132-133), já é muito tarde para os mortais no abandono dos deuses, como retornar a casa em tempos de niilismo, enquanto perda de lugar? Para isso, é necessário pensar na história da fuga da origem, enquanto história da metafísica, e explicitar o lado moderno dessa história, que culmina no "negativo fotográfico" do Ereignis primordial e que, no esgotamento de suas possibilidades e no reconhecimento de seu caráter diametralmente oposto ao originário, permite caminho para o retorno ao lugar. Portanto, seria necessário compreender o que Heidegger tem em vista ao falar desse "negativo", para poder lidar com a questão em sua amplitude.

Heidegger se pergunta, em A questão da técnica (2000, p. 5-36), conferência realizada em 1953, em Munique, sobre a essência da técnica. Ao realizar essa pergunta, ou melhor, ao colocar a técnica em questão, o filósofo não pretende encontrar a sua substância essencial, posta em um conceito totalizante que possa ser encontrado em uma resposta tal como, por exemplo, "técnica é todo tipo de artifício que sirva a determinado fim" ou "técnica é a atividade subjetiva de transformação do mundo" — definições que Heidegger afirma fazerem parte de uma "determinação instrumental e antropológica da técnica" (ibid. p. 8, trad. nossa), dominante na metafísica ocidental. Essência, como dito acima, é, para Heidegger, lugar de proveniência; portanto, ao questionar a essência da técnica, se remonta a suas origens, ao acontecimento de seu ser e, portanto, ao Ereignis e à alétheia que doaram a ela seu sentido, temas da seção anterior. É assim que Heidegger pretende chegar ao que ele compreende como sendo o "negativo fotográfico" do 
Ereignis primordial e que pode, enfim, abrir espaço para um retorno ao $\mathrm{lu}$ gar. Dessa forma, não se deve responder à questão da técnica fazendo referência aos artefatos ou formalidades que se constituem ou usam da técnica para atingir determinados fins, conformes à vida humana e a seus desejos e propósitos, mas à doação de seu ser.

A escolha de Heidegger por “Technik” — termo alemão que carrega tanto a conotação mais genérica do nosso "técnica", quanto a conotação mais específica de "tecnologia" — deve-se à origem comum da qual emergem as técnicas antigas e as modernas tecnologias, ou melhor, à mesma essência, ao mesmo lugar de aparição enquanto acontecimento de doação de ser. Contudo, há uma diferença específica no modo como, na contemporaneidade, o desvelamento decorrente da técnica (Technik) age, mais do que

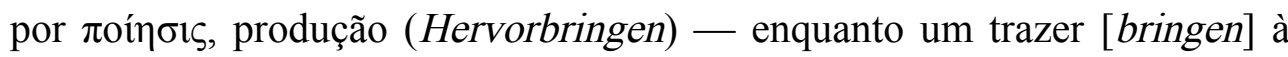
tona ou à frente [hervor] o ente em seu ser mais próprio, como acontecia entre os gregos originários - , por exploração ou provocação (Herausfordern), isto é, algo como exigir [fordern] que venha a fora [heraus] ou, ainda, que se explicite e exponha o ente, arrancando-o ao desvelamento como algo outro do que o de sua vigência mais própria. Dessa forma, o ente é forçado a revelar-se como estoque de forças esvaziado de qualquer outro sentido, recurso à disposição ou fundo de reserva (Bestand) (cf. HEIDEGGER, 2000, p. 1518). Para Heidegger, a técnica revelada nesse modo de desencobrimento tem sua essência no que o autor denominou por Gestell (ibid. p. 20), e que, para ele, configura o negativo da Ereignis primordial. ${ }^{7}$ De maneira completamente distante, mas ao mesmo tempo ela mesma como um Ereignis, partilhando de uma vizinhança primordial, no sentido de ser também uma mútua apropriação dos polos da quadratura na presentação do ente de determinada for-

\footnotetext{
${ }^{7} \mathrm{O}$ termo Gestell, formado pela adição do radical Ge- à substantivação do verbo stellen, "posicionar", "pôr", tem um sentido coloquial diferente das intenções de Heidegger, pois designa toda forma de armação ou estrutura de suporte. No uso heideggeriano, enquanto Ge-stell, designa, pelo prefixo de união Ge- (presente, por exemplo, em Gebirge, cordilheira ou serra, enquanto força de reunião e desdobramento de um conjunto de montanhas [Berge]), o lugar de reunião de mundo em que o ente se mostra de forma assinalada, a saber, como recurso disponível. Opera, portanto, de forma análoga ao Ereignis (sendo, assim, também um Ereignis), mas com o seu desencobrir acontecendo de forma outra e revelando algo diametralmente oposto ao acontecimento originário. Como esse termo é, assim como Ereignis, alvo de uma miríade de traduções (composição, armação, arrazoamento, arraisonement, enframing, enowning, positionality etc.), permanecerá também sem tradução neste trabalho.
} 
ma, a Gestell desdobra o ser dos entes e dá medida a uma ontologia histórica que, para Heidegger, é a ontologia vigente na contemporaneidade ocidental.

A diferença entre a téchne como poíesis da antiguidade grega e a tecnologia exploratória da Gestell moderna está na forma de desencobrimento do ente (cf. HEIDEGGER, 2000, p. 21-22). O real, para o homem grego, era palco do jogo do mundo: os mortais se defrontavam com seu destino, ou seja, com o acontecimento do mundo em todo o seu vigor; assim, terra e céus não se constituíam objetos frios e inertes à disposição de estudo intensivo e dissecação, mas horizontes inescapáveis, fundamentos inescrutáveis, doando a ele o sentido de sua existência ao mesmo tempo em que vedava, muitas vezes, o acesso a eles sob forma de intempéries e tormentos. O homem trágico, por sua vez, media-se com seu limite mortal pela tradição que o envolvia, pela cultura em que dialogava, pelo senso de sagrado que testemunhava e, no limiar, o escapava; o homem era implicado com o destino que o enviava e o envolvia, e era ele quem, no testemunhar desses acontecimentos, abria espaço, junto aos deuses, para a vigência do mundo no seu acontecimento mais próprio.

É nesse contexto que, pela técnica originária, construíam-se, por exemplo, moinhos de vento humano, que não utilizavam das correntes de ar como um reservatório de energia, mas que deixavam-se afetar pelo ar que advinha de seu movimento mais próprio. O diverso ocorre, por exemplo, com a usina sobre o rio, que, desviando o curso do rio de acordo com as finalidades energéticas da nação, subjuga-o a seus propósitos (postos pela essência da técnica, que também subjuga a usina às demandas populacionais, a finalidades políticas e diplomáticas, ao turismo exploratório e à exposição midiática). Sendo assim, o humano contemporâneo, ao contrário do trágico grego, disseca o mundo como um laboratório, dispondo dele como um imenso e infindável banco sistemático de dados uniformes, calculáveis, consumíveis; há ausência de mistério, e os mais recônditos cantos do universo são visualizáveis por telescópios astronômicos, bem como as mais elaboradas teorias científicas são postas a prova para explicar o que há de mais complexo e distante do habitar humano; é o humano que, provocado e dominado por esse modo de se desencobrir, desvela o real com violência, sacando o ente ao aparecimento de acordo com a dinâmica mesma da provocação, 
que faz tudo reluzir como estoque operativo de forças sem qualidade e diferença, e mesmo o humano é enredado nessa dinâmica infindável de desqualificação planificadora, servindo de ponto em meio aos pontos de uma rede homogênea de provocação e exploração (cf. HEIDEGGER, 2000, p. 54).

Como em um sonho lúcido, na tentativa de forçar o mundo a seu arbítrio, sem se dar conta de que se opera como recurso, dado sem qualidade, da dinâmica mesma que provém da própria forma de operação do sonho ele mesmo, o humano se perde de sua essência enquanto testemunha do acontecimento do ser. A essência, acontecimento primordial que provê ele próprio a destinação do humano na Gestell, se encobre para o humano e, com isso, se encobrem outras possibilidades que não às fornecidas pela Gestell e, portanto, outras possibilidades de ser dos entes que não como recursos disponíveis (cf. HEIDEGGER, 2000, p. 26-27). Perder-se da essência é perder-se da origem, da proveniência do lugar. Assim, o humano da era da Gestell é o humano da errância, o homem que tem de reencontrar seu lugar. No fechamento da história da metafísica com a Gestell, diante da evidência do próprio acontecimento da maquinação moderna, no "perigo extremo" (ibid. p. 33, trad. nossa) da dominação incondicional do humano pela lógica da Gestell, em que se torna clara sua condição de desenraizado, é que se abre caminho para a inversão e o retorno ao lugar primordial, "num domínio que, de um lado, seja consanguíneo com o da essência da técnica e que lhe seja, de outro, fundamentalmente diverso" (ibid. p. 36, trad. e grifos nossos). É, pois, no torvelinho da Gestell que se abre a possibilidade de outro começo, enquanto um retorno do habitar primordial.

Se é necessário um passo de retorno, torna-se importante compreender o caminho que a metafísica levou para chegar à consumação máxima de seu esquecimento que é a Gestell, no sentido de desconstruir a metafísica de seu interior para compreender em que medida se tornou possível a inversão da Ereignis originária a partir de sua própria proveniência. Esse caminho não pode, se quisermos seguir Heidegger, ser vislumbrado fazendo somente uma historiografia da técnica ou dos meios pelos quais o humano chegou a desvendar o ente na totalidade como fundo de reserva. Deve, mais fundamentalmente, remeter à história das mudanças no âmbito da verdade, da alétheia, enquanto acontecimento de surgimento de ontologias, Ereignis. A 
consumação do esquecimento, de acordo com Heidegger, se dá pelos acontecimentos sucessivos de ontologia que se desdobraram do esquecimento do ser entre os gregos. Parte dessa história se evidenciou na seção anterior: a anulação da diferença e da obscuridade da alétheia a favor da metafísica da presença constante em Platão e Aristóteles. Em seguida, o Medievo, trasladando a alétheia grega em veritas romana, consolidou a adæquatio e, com isso, o predomínio da linguagem proposicional sobre o acontecimento do ser, bem como do ente supremo como causa primeira e presença constante em meio à multiplicidade, personificado na figura ontoteológica de Deus como causa eficiente do ente na totalidade. O próprio intellectus ao qual as coisas, rei, tem de se adequar na proposição não é senão, primordialmente, o intellectus divino, ao qual o intellectus humano segue como derivação limitada e finita (cf. AQUINO, 2002, p. 171-181). O passo decisivo para a consumação da técnica foi, contudo, a transferência do papel de essentia primordial e hypokeímenon, enquanto subjectum, que repousava na figura ôntica do ente na totalidade criado por Deus (Creatio) - e, portanto, no próprio Deus enquanto unidade fundante - durante a Idade Média (cf. CARDOSO, 2010, p. 48), para o pensamento humano do sujeito egóico, enquanto uno fundante de suas próprias representações.

Ao cabo dessa trajetória, Descartes erige-se como aquele que assume, ao menos em método, o "eu" que pensa (ego cogito) como princípio fundante das representações (cf. DESCARTES, 2004, p. 27), "sujeito" no emergente sentido moderno, enquanto auto asseguramento do ente que intui e abarca um âmbito objetivo de representações (cf. HEIDEGGER, 2000, p. 84-85). São nas reflexões não somente de suas Meditações, como também de Discurso do método, dentre outras obras, que o filósofo francês chega à conclusão de que, como fruto de uma dúvida hiperbólica acerca da existência do mundo exterior, fora da consciência daquele que pensa e duvida, o fundamento inconcusso do real, a nível epistemológico, não pode ser outro que o próprio ego, substância pensante (res cogitans) e, nesse sentido, subjetiva, enquanto substrato formal, subjacente e permanente à multiplicidade de representações ou ideias (cf. DESCARTES, 2004, p. 28). Mesmo ainda considerando Deus como um princípio e fundamento em si na ordem ontológica, isto é, enquanto causa suma do ser, não é, porém, na ordem 
epistemológica, concernente aos limites do sujeito finito do conhecimento, que Deus vai assumir estatuto de subjectum fundante, mas sim é o próprio sujeito quem vai assumi-lo no seu movimento retroativo constante de pensamento em dúvida. O pensamento (cogito) finito do sujeito, dessa forma, se ampara na substancialidade de um res, necessariamente coimplicados.

Em suma, o que interessa na metafísica cartesiana, pensando "metafísica" na perspectiva heideggeriana da busca pelo ser do ente em geral, é sempre o campo epistemológico, fundante do conhecimento possível do mundo para um ego que se restringe, quanto à cognoscibilidade, ao âmbito restrito e finito de suas representações (cf. CARDOSO, 2010, p. 67). Por isso, o ser do ente em Descartes não é outro que a própria subjetividade, no sentido do "caráter essencialmente ativo da subjacência, que propõe a vinculação como ser e unidade das instâncias Deus, coisa extensa e coisa pensante e ato supremo de uma delas (Deus)" (ibid. p. 68). A subjetividade, de ordem epistemológica, que é, em sentido cartesiano, a própria ordem metafísica da fundação do conhecimento, é a própria essência da verdade que ampara a unidade da totalidade do real, concebido não como existência em si do ente que, de princípio, torna-se agora algo de incognoscível (ibid. p. 67), mas como aquilo que é contraposto ao sujeito como representação (perceptio) sua, isto é, como ob-jectum, ob-jeto, "contra-posto", (Gegen-stand). ${ }^{8}$ Realidade (Wirklichkeit), em Descartes, reduz-se à objetividade (Gegenständlichkeit) (ibid. p. 43) - e isso, Heidegger já concluíra desde Ser e tempo (cf. HEIDEGGER, 2012, §23). Por isso, a epistemologia que circunscreve a modernidade, segundo Heidegger, não é nada mais do que uma ontologia que se pauta na própria objetividade do sujeito egóico como ser do ente na totalidade: ela é, como tal, metafísica da representação ou "metafísica do objeto" (id. 2000, p. 73, trad. nossa).

Mais fundamentalmente do que isso, a essência da verdade enquanto subjetividade, na qual se funda a modernidade, configura-se a partir da redução, efetuada durante a transição escolástica que culmina em Descartes, da

\footnotetext{
${ }^{8} \mathrm{O}$ substantivo alemão Gegenstand significa "objeto", mas literalmente, pode significar algo como "o que está contra, diante" (donde o verbo standen significar "ficar em pé" ou "estar em pé"). Em alguns casos, quando necessário, como quando houver ocorrência dos termos alemães Objekt e Gegenstand na mesma frase ou quando for preciso salientar esse caráter opositor, utilizaremos a noção de "contraposto" para acentuar essa característica etimológica.
} 
própria veritas qua adæquatio para veritas qua certitudo (verdade como certeza) (cf. HEIDEGGER, 2000, p. 83), em que a adequação se submete à evidência sempre presente e auto asseguradora do intelecto enquanto "alma", ou seja, do sujeito pensante (cf. ibid. p. 72). A auto asserção do pensar, com a finalidade de amparar a multiplicidade do real no asseguramento reflexivo de um sujeito formal constante que acompanhe e dê consistência à multiplicidade de representações objetivas, vai se firmar posteriormente naquilo que se tornaria sustentáculo do conceito de vontade de poder (Wille zur Macht). Para Heidegger, tal conceito é de importância nuclear na filosofia de Nietzsche, provedora do acabamento da metafísica: a vontade de querer (Wille zum Willen), enquanto "asseguramento forçoso e completo de si mesma" (ibid. p. 86, trad. nossa) que atua desvelando a "realidade objetiva" dos modernos, isto é, o ente na totalidade, como um eterno retorno do mesmo (ewige Wiederkehr des Gleiches).

Para Heidegger, o pensamento de Nietzsche, essencial como um momento de um período histórico singular, é um pensamento metafísico que prenuncia com todas as palavras a dinâmica da Gestell. Assim, o inventor do Zaratustra veda a metafísica por dentro, expondo todos os seus limites e, ainda, operando como um metafísico. Com Nietzsche, o ente humano, como Übermensch, ciente da metafísica na qual se vê enredado, consuma seu papel central enquanto sujeito absoluto do real, assumindo a criação arbitrária do sentido do ente na totalidade. Com isso, o humano se efetiva como vontade de poder. A vontade de poder, porém, fundando-se na vontade de querer da subjetividade asseguradora, é uma vontade que escapa ao mero querer humano, pois ela é a própria essência do ser após o advento da subjetividade. Sendo assim, o próprio humano é requerido pela vontade de querer, se tornando "objeto" em uma dinâmica de objetificação absoluta, em que tudo se torna eterno retorno do mesmo, o que implica em dizer que tudo se torna recurso disponível (Bestand) (cf. HEIDEGGER, 2000, p. 92). O ente humano, nesse sentido, se torna matéria-prima do sujeito da subjetividade que é a própria vontade de querer, Gestell.

Ocorre em paralelo à morte de Deus, a morte do sujeito humano em detrimento da subjetividade impessoal da Gestell. Os polos da quadratura se vedam. Os deuses abandonam os mortais, que passam à penúria da ausência 
do horizonte da mortalidade, entregados às ocupações técnicas e ao planejamento sem fim; o céu torna-se vácuo, onde se postam os mais recônditos cantos do universo ainda à espera de exploração; a terra torna-se geometria calculável e depósito de minérios e combustíveis, bem como campo de exploração agrícola ou arqueológica e espaço para estudo geográfico e planejamento urbano. $\mathrm{O}$ ente como um todo se planifica como não-ente, como valor, como recurso, como operatividade. A humanidade se prostra, agora, sobre o "vazio do ser" (HEIDEGGER, 2000, p. 94, trad. nossa), no qual reina a uniformidade, a ausência de hierarquia, a indiferenciação extrema. Com o abandono de deuses e homens, céu e terra, perde-se sentido Ereignis e alétheia, tempo e espaço e, com isso, o lugar, esvaziados na formalização infindável de tempo e espaço vazios. "A terra aparece como o desmundo [Unwelt] da errância" (ibid. p. 96, trad. nossa), tal qual o humano, que padece da penúria de sua vã, poderíamos dizer, "u-topia” (ou-topía, "não-lugar”), que, em sentido assinalado, é o mesmo que o desalojamento do humano da técnica com relação à origem, à terra natal, ao lar (cf. id. 1976, p. 338).

\section{Linguagem como lugar}

Se linguagem, para Heidegger, é casa do ser, tópos, o obscurecimento do lugar, no esgotamento do ser dos entes na vontade de querer planificadora da Gestell, também tem repercussões sobre a linguagem, que passa a se mostrar como mera expressão subjetiva e, no limite, como formalização vazia e carente de sentido. A pretensão humanista de domínio do ente na totalidade em que se pauta o sujeito moderno torna-se a própria objetificação do humano. Da mesma forma, se coloca a questão: seria o humano, senhor da linguagem, ou seria dela seu servo? Ao tornar não só análogos como coincidentes os acontecimentos de linguagem e lugar, Heidegger já responde: o mortal, como testemunha da quadratura, é tão somente servo da linguagem (cf. HEIDEGGER, 2000, p. 193-194), prostrado em sua escuta e pertença, mesmo na pretensão inútil de seu controle, que apenas obscurece sua proveniência originária e o recoloca a serviço do acontecimento do ser como Gestell. 
Mas, assim, não se torna claro senão de forma meramente provisória e preliminar o que é a linguagem em Heidegger e de que forma a colocação do problema da linguagem realmente se vincula com o problema do lugar, central para esta dissertação. Carece, portanto, de esclarecimento a maneira como o filósofo pensa a linguagem, ela mesma, em sua obra tardia, sobre que pano de fundo se encontra a discussão e quais as implicações que o esvaziamento da Gestell tem sobre a linguagem. Com isso, também se abre espaço para a compreensão da relação entre subjetividade e linguagem na obra tardia de Heidegger.

Sendo assim, é necessário retomar brevemente a discussão de Heidegger sobre a linguagem, exposta com mais evidência em textos como $A$ linguagem, $A$ essência da linguagem, e $O$ caminho para a linguagem. Nesse contexto, é necessário retomar a primeira parte de sua conferência de 59, $O$ caminho para a linguagem (HEIDEGGER, 1985, p. 227-257), onde se erige a problemática da relação entre subjetividade e linguagem, no qual o filósofo dialoga com Da interpretação, de Aristóteles.

Por um lado, Novalis acena para o pensador uma experiência originária com a linguagem, obscurecida pelo nosso uso cotidiano dela: a própria linguagem fala sozinha, em monólogo, e esse é o maravilhoso e o misterioso da linguagem, que acomete os homens em um espanto por lhes ser absolutamente estranho (cf. NOVALIS, 1988, p. 195-196). O ente humano é, por outro lado, aquele que se considera dono da linguagem, seu criador e articulador. A própria palavra "linguagem", nas línguas derivadas do latim e do grego, suscita um órgão vocálico: a língua. No alemão, Sprache (linguagem) é substantivo para o verbo sprechen (falar), que concerne à fala enquanto articulação de sons (cf. HEIDEGGER, 1985, p. 232). Assim parece ocorrer com a passagem inicial de Da interpretação, tão mal interpretada e deslocada semanticamente de seu âmbito hermenêutico original pelos estoicos e escolásticos, segundo Heidegger. Aristóteles, na tradução heideggeriana, livre do distanciamento absoluto entre signo e significado característico da teoria da linguagem estoica (cf. NEF, 1995, p. 29-30), teria aberto seu texto dizendo que "o que (se põe em direção [sich begibt]) no pronuncia- 
mento vocal é um mostrar [Zeigen ou symbola] do que se dá nas paixões da alma, e o [texto] escrito é um mostrar dos sons vocálicos." (apud HEIDEGGER, 1985, p. 233, trad. nossa). Mesmo não havendo, no entanto, uma corrente de significação causal da qual suas traduções usuais são vítimas, há preponderância do "pronunciamento vocálico" na concepção de linguagem aristotélica, que viria a se dedicar a sistematizar uma lógica e conceber a linguagem a partir da proposição (Aussagen), pensando o ente pelo seu caráter de hypokeímenon da sentença, sujeito lógico passível de predicação de características e modos contingentes.

É preciso se lembrar do que foi dito na seção anterior a respeito de como a predominância da substancialização, própria da assunção do hypokeímenon aristotélico, mas referente ao prévio deslocamento da essência da verdade em Platão, foi basilar para a configuração que a verdade do ser veio a ter na escolástica da adæquatio, na modernidade do cogito e na contemporaneidade da vontade de poder. Por todo esse caminho, manteve-se uma espécie de "determinação antropológica da linguagem", isto é, a determinação da linguagem como produto da fala do humano. Já em Aristóteles, isso era claro: zóon lógon êkhon também pode ser pensado, como na Grécia tardia do estagirita, segundo Heidegger, como o vivente (zóon) "que tem a capacidade de falar [lógon êkhon] e que, portanto, já possui linguagem [lógos]." (HEIDEGGER, 1985, p. 229, trad. nossa) Com os escolásticos, o animal rationale se tornou o animal que, possuindo linguagem, podia se distanciar da animalidade e corresponder ao Verbo de Deus, perfazendo-se, assim, sua imagem e semelhança. Então, a passagem referida há pouco de Aristóteles já podia se justificar da forma moderna como aparece em suas traduções mais comuns: "as palavras faladas são símbolos das afeições da alma, e as palavras escritas, símbolos das palavras faladas" (ARISTÓTELES, 2010, p. 18), no qual o distanciamento entre a fala como símbolo refe-

\footnotetext{
$\overline{9}$ O termo Zeigen ("mostrar") é da própria interpretação de Heidegger, não sendo tradução direta do grego symbola. O original grego aparece para indicar apenas o momento, no texto de Aristóteles (1949, p. 49), em que a noção de "mostrar" parece mais cabível ao filósofo alemão do que a mera noção moderna de "símbolo". Em A origem da obra de arte, Heidegger usa um cognato, symbállein, quando fala da obra de arte como "símbolo": um "com-por [Zusammenbringen]" (HEIDEGGER, 1977, p. 9, trad. nossa), ou seja, um reunir que põe em conjunto e mostra. O grego symbola, portanto, mais do que simplesmente "símbolo", como compreendido no uso corrente, é, para Heidegger, da própria ordem da mostração de um conjunto (no caso, das paixões da alma) reunido na fala (ou na escrita, como reunião dos sons da fala).
} 
rente àquilo com que a alma se afeta é evidente. Assim, se abre caminho para que, na modernidade, a linguagem como fala se subjugue à representação da alma que, intuindo, constrói suas representações (afeições da alma) a partir de sua própria fundamentação formal. A linguagem se torna - como é para Wilhelm von Humboldt (1988), um dos interlocutores de Heidegger na conferência - expressão ativa do espírito humano - um dentre outros produtos da atividade antrópica, instauradora em primeira instância do mundo fenomênico.

Junto a essa determinação antropológica da linguagem em von Humboldt, encontra-se mutuamente implicada sua acepção instrumental. A linguagem é, enquanto a própria atividade de expressão do pensamento, um instrumento para esse mesmo fim (cf. VON HUMBOLDT, 1988, p. 79). Como um instrumento, um meio para um fim, ela se enquadra na teoria da causalidade: se constitui de matéria (sons e impressões ou ideias) e forma (a própria atividade de articulação sonora), possui um determinado fim, constituído na própria expressão e, de forma derivada, na comunicação, e esse fim sempre vem conjugado ao arbítrio eficiente humano (cf. VON HUMBOLDT, 1988, p. 51-52). Portanto, as duas determinações - antropológica e instrumental - estão coimplicadas, de maneira extremamente próxima a qual se mostra na discussão da essência da técnica por parte de Heidegger (cf. 2000, p. 8), o que demonstra que a concepção de linguagem humboldtiana é estritamente técnica, derivada de sua instrumentalidade antropológica. No entanto, da mesma forma que, na busca da essência da técnica (ontológico), não importa para Heidegger o que é técnico (ôntico), na busca da essência da linguagem também não importa a linguagem enquanto gramática, filologia, etimologia, linguística, filosofia da linguagem etc. pois toda forma de investigação e sistematização têm pretensão de analisar a linguagem externamente, reduzindo-a a um objeto, instrumental e antropológico, que escapa à experiência da linguagem ela mesma - ainda que, sempre, submetida a seu acontecimento originário (cf. HEIDEGGER, 1985, p. 234).

Portanto, enquanto pensa a linguagem na problemática tensão entre criação e tradição, von Humboldt já vem pressupondo-a como um tipo de atividade humana, instrumento entre outros de expressão da própria subjetividade, reduzida a um ente entre outros, passível de análise e dissecação. O 
antropólogo mantém-se nos liames da metafísica e abre caminho, dessa forma, para a formalização cada vez mais profunda da linguagem, que já estava em vias de se perfazer, e que se coaduna com a formalização e o esvaziamento do real na época da Gestell. Também a linguagem, reduzida à expressão, perde-se na dinâmica do eterno retorno e se torna formalização vazia, enquanto instrumento de cálculo sem diferenciação, com o intuito de realimentar a corrente de exploração e provocação dos entes pelo mero intuito de explorar e provocar, requerimento constante da vontade de querer infinita e despropositada.

No fim das contas, também a "crítica" de Heidegger a von Humboldt não é uma crítica no sentido de comparar erros e acertos do autor, a fim de consertar o que nele havia de errado e manter o que nele havia de correto. A estratégia argumentativa de $O$ caminho da linguagem é, novamente, a mesma de $A$ questão da técnica: a linguagem enquanto atividade de expressão do sujeito não é uma concepção falsa e falaciosa do que viria a ser linguagem, assim a concepção antropológica e instrumental da técnica não é falsa em frente à técnica como Gestell. Todas as concepções derivativas estão corretas, mas mesmo assim não "chegam à verdade", isto é, não se encaminham à proveniência originária da qual são derivadas, e não permitem pensar a abertura originária da linguagem. Dessa forma, von Humboldt, assim como Nietzsche, é porta-voz de um período de indigência que, por outro lado, aponta para o caminho de retorno (Kehre), ou seja, para utilizarmo-nos das palavras de Hölderlin em Patmos (1991, p. 181), para a "salvação" no lugar "onde há perigo".

Salvação no mesmo lugar onde há perigo, devemos salientar. A mesma conferência em que Heidegger fala sobre a técnica e cita esses versos de Patmos (cf. HEIDEGGER, 2000, p. 29) é iniciada com uma reflexão sobre o questionamento, enquanto traçado de um caminho do pensamento. "Todo caminho do pensamento se conduz" (ibid. p. 11) acena o pensador, "mais ou menos perceptivelmente, de um modo não habitual [ungewöhnliche] através da linguagem." (ibid. trad. nossa) O caminho é feito sempre, mesmo que isso não se tenha em evidência e nos pareça estranho e extraordinário, sobre $o$ solo da linguagem, e nunca em direção a ela. A linguagem, aqui, é essência histórica de onde provém o mundo, tópos, casa do ser na qual, ouvindo 
novamente o apelo hölderliniano, "poeticamente / habita o homem" (in id. 2001, p. 257). Poesia (Dichtung) e pensamento (Denken) confluem no caminho da linguagem, essa que, para os gregos, surgia sobre o nome de lógon, forma substantivada do verbo légein, dizer e falar.

Mas com isso não se retorna à concepção apofântica de linguagem como expressão, como afirma von Humboldt? De acordo com o antropólogo, linguagem é um instrumento de expressão humana. Com essa determinação, a linguagem vem imbuída de quatro causas, já aludidas acima, refletindo, em sua instrumentalidade, o trabalho técnico daquele que fala.

É necessário, contudo, refletir, junto a Heidegger, sobre o que os gregos originários concebiam por "causa" (Ursache), tradução do termo "aítion” (cf. ibid. 2000, p. 10), a fim de compreender o que está em jogo por trás da concepção humboldtiana de linguagem, de acordo com a perspectiva do pensador do ser. A palavra "coisa” possui ressonância do latim "causa", e mesmo nessa língua, o termo já possuía reverberação semântica de "reunir", "pôr em causa"; no alemão, também, Ursache ressoa o substantivo "Sache", no papel de sufixo, que pode ser traduzido por "coisa", mas também, no âmbito jurídico, por "causa", "questão".

Heidegger (2000, p. 10), de forma análoga, afirma que os gregos tinham por aítion o sentido de "responder" e "dever" (para ambos, no alemão: verschulden ${ }^{10}$ ). Esses dois termos devem ser pensados na experiência não moral dos gregos originários como dois modos copertencentes de propiciar que algo venha à tona, no sentido de abrir espaço e dar condições para seu aparecimento - ou seja, no sentido de poíesis, pro-por, pro-duzir. As quatro causas, pois, são originariamente modos de responder e dever, ocasiões para o acontecimento da coisa como reunião da quadratura, ou seja, são modos de poíesis (cf. ibid. p. 12). Dentre elas, o próprio artífice "eficiente" da coisa — o falante — não é elemento central e instaurador na criação da coisa, mas apenas ocasião para o surgimento da coisa a qual responde e deve. No seu fazer - neste caso, linguístico — , o falante abre espaço para reunião de matéria, forma e finalidade, como três modos de poíesis, e assim permite o aparecimento da coisa, isto é, dá voz à linguagem.

\footnotetext{
${ }^{10}$ Em tradução literal, "causar", mas também "dever por...", "ser responsável por...", "responder por..."
} 
Para Heidegger, essa reunião que perpassa o falante e o convoca a dar voz, da mesma forma que a reunião que convoca o ourives a trazer à tona e responder pelo cálice de prata, é fundamentalmente lógos. Dizer e falar, pois, são resultados de uma reunião, prévia à atividade da fala, proveniente do lógos - ele mesmo, que no grego originário de Heráclito tem, mais do que dizer ou falar, os sentidos de pro-por (beisammen-Anwesenden, "presentar-em-conjunto") e de-por (vorliegen-Lassen, "deixar-presentar"), ou seja, de reunir um conjunto em uma unidade e de deixar com que o conjunto vigore por si mesmo (cf. HEIDEGGER, 2000, p. 232-233).

Deixar que o ente seja, que o ente vigore a partir de seu velamento, ou seja, poíesis, seja como téchne ou como physis, provem da alétheia, do des-encobrimento originário. Légein, “dizer”, nesse sentido, é alétheia ou, nas palavras heideggerianas, dizer (Sagen) é mostrar (Zeigen $)^{11}$ - sendo que “dizer" é, para Heidegger, "o essenciante [Wesende] da linguagem" (HEIDEGGER, 1985, p. 242), ou seja, o solo que, como origem ${ }^{12}$, permite a linguagem usual, expressiva. Sendo assim, "a essência da linguagem", argumenta Heidegger,

[...] não se esgota na significação, nem é ela apenas algo do gênero do signo ou do número. Sendo a linguagem a casa do ser, chegamos ao ente passando constantemente por essa casa. Quando vamos ao poço, quando passeamos na floresta, passamos já pela palavra 'poço', pela palavra 'floresta', mesmo quando não pronunciamos essas palavras, nem pensamos na linguagem. (HEIDEGGER, 1977, p. 286, trad. nossa)

Antes de expressão ou designação, portanto, a linguagem, como dizer, é o âmbito da primordial presentação do ente na totalidade, no qual habitamos como mortais que falam a nela e a partir dela - ela é lugar. A nomeação originária, que, como mostra Pádua (cf. 2005, p. 246-247), é “evocação", ou seja, um "trazer algo da distância", um "des-afastar", ao mesmo tempo em que, na palavra, reúne todo um mundo, provém da linguagem, e é só como coisa nomeada que o ente, em meio a ela, tem seu ser. A linguagem (o lugar), portanto, é quem, em silêncio, diz (abre), e o humano apenas escuta (hört) à linguagem (a ela pertencendo [gehört]), dando a ela

\footnotetext{
${ }^{11}$ Novamente, "mostrar" também como "reunir", "juntar", “com-por", como dito em nota mais acima.

${ }^{12}$ Ou seja, "essenciante" compreendido como "originante".
} 
voz, ou seja, dando voz a uma situação histórica (cf. HEIDEGGER, 2000, p. 220). Linguagem é monólogo e o humano é diálogo a partir dela, em sua casa, testemunhando o advento do mundo, em todos os seus polos e no seu duplo caráter de encobrimento e descobrimento. Assim, linguagem é fundamentalmente tópos, "meio universal" (KUSCH, 1989) em que se erige o mundo do humano, dando a um povo histórico e situado, medida e sentido. Nesse interior, em meio ao tópos da linguagem, emerge a proximidade inefável, mas sempre experienciada, dos polos da quadratura, que habitam no jogo topológico de espelho na vizinhança, isto é, na relação mútua de uns com os outros, na qual cada coisa está aberta a se estende até a outra, mantendo-se ainda em seu ser mais próprio (cf. HEIDEGGER, 1985, p. 197198). Em meio a esse jogo topológico, também os mortais se refletem em sua relação interfacial, constituindo, em conjunto, um mundo próprio.

Portanto, é como tópos que a linguagem congrega céu, terra, mortais e deuses - ou seja, alétheia e Ereignis, espaço e tempo, atuando na diferença ou inter-secção (Unter-schied) de mundo e coisa (cf. HEIDEGGER, 1985, p. 22), isto é, em seu jogo topológico de unidade, diferença e codependência. Cada acontecimento histórico é, portanto, provido e instituído pela linguagem, lógos, a cada etapa da história de manifestação e retração do ser, situando de determinada maneira a cada vez um povo histórico. Linguagem, dessa maneira, mais originariamente do que dizer como fala e expressão, é um dizer monológico da própria linguagem como lógos, acontecimento de reunião da quadratura que abre espaço (e tempo) para o advento de coisa e mundo em sua dinâmica de unidade e diferença, bem como retração e claridade. Daí, a própria noção de "topologia" não designar um "discurso" ou uma "teoria sobre o lugar", mas sim a própria ontologia como "dizer do lugar" (MALPAS, 2006, p. 33, trad. nossa), em que tópos e lógos se mostram como o mesmo, isto é, como reunião propiciadora de mundo e coisa, ser e entes, em sua unidade e multiplicidade - em outras palavras, "casa do ser".

Poesia e pensamento não são, nesse sentido, duas figurações expressivas do falar, mas duas possibilidades, próximas e vinculadas, de habitar $o$ próprio lugar do acontecimento de instituição inauguradora como reunião de mundo e manifestação de coisas que é a linguagem. Por um lado, a poesia 
nomeia, produzindo e dando condições, o sagrado, perfazendo sua atuação linguística como nomeação inaugural do ente, provendo medida ao mundo histórico manifesto no Ereignis. Por outro lado, o pensamento diz o ser da contemporaneidade, dando a ele voz e expondo sua manifestação mesma (cf. HEIDEGGER, 1976, p. 311-312). O primeiro caso, de forma exemplar, Heidegger vê em Hölderlin, que acena o abandono dos deuses e a salvação em meio ao perigo; o segundo, por outro lado, em Nietzsche, traduzindo o chamado contemporâneo do ser na morte de deus e na afirmação do eterno retorno. Nomear o sagrado e dizer o ser; pro-por e de-por; edificar e cultivar.

Edificar e cultivar, como outrora mencionado, são, para Heidegger, dois modos de construir, bauen, proveniente do antigo alemão, "buan", que originariamente significa habitar (wohnen). Habitar poeticamente é, portanto, habitar no cultivo pensante do ser ausente na manifestação do ente na totalidade e dar lugar para a dinâmica histórica do ser em seu acontecimento vindouro, no prenúncio de outro começo possível para a história do ser. Dessa forma, o habitar poético não é exclusividade do poeta, mas é soterrada pela história, a condição originária do humano, pastor do ser que, como testemunha e guardião, preserva o ser no seu lugar próprio. Esse habitar é o que se perde na história da metafísica, pois se perde o próprio lugar do ser — e, portanto, se perde a casa da linguagem. Perder a casa da linguagem vincula-se à tentativa de perscrutá-la até o íntimo, de exceder seus limites e de reduzi-la a objeto de manipulação e formalização, esvaziando-a de seu suceder autêntico, concebendo-a como cálculo e informação arbitrária, vazia e homogênea (cf. HEIDEGGER, 1989, p. 25).

Mas, sendo a Gestell uma forma de desencobrimento, e sendo ela a forma de desencobrimento por excelência na contemporaneidade, também a Gestell é manifestação da linguagem, no mesmo sentido em que é seu retraimento máximo. Na era da Gestell, a linguagem é um depositório de recursos e informações disponíveis a serviço da dinâmica de eterno retorno infindável do niilismo. A linguagem esconde-se como tópos e também ela se manifesta "outopía" - a "utopia" da linguagem puramente formal, sintaticamente perfeita, universal para toda e qualquer semântica e independente até mesmo da pragmática cultural, linguagem "maquinal" (cf. HEIDEGGER, 1989, p. 26-27). No limite, a linguagem da Gestell não é mais 
que pontos e axiomas homogêneos, sem dimensão e intercambiáveis, e a tradição de um povo se dissolve em criação arbitrária, história manipulável, informação jornalística e biográfica - e, no limite, à linguagem binária sem distinção de um processador de dados. Da linguagem, o que resta é a informação, disponível de forma uniforme por todo o globo e sem diferenças qualitativas, em que "o próprio da linguagem está atrofiado, isto é, reduzido à mera doação de sinais, ao informar." (HEIDEGGER, 1989, p. 26, trad. nossa)

A formalização e informatização da linguagem, enquanto tentativas de perscrutar no íntimo e mais profundo da linguagem, em sua estrutura mais primordial, a fim de se utilizar da linguagem como de um instrumento de expressão unívoca, difusão de informação planificada e manipulação da natureza, disponível para uso abusivo e arbitrário, não sucedem no feito, por escaparem à experiência mais própria da linguagem, situada dentro dos limites de seu apelo. Nesse sentido, "também a teoria da informação da linguagem vai, necessariamente, de encontro a um limite." (HEIDEGGER, 1989, p. 26, trad. nossa) Na tentativa de levar a linguagem aos limites do claro, e de transpor esses limites, não se faz mais do que obscurecer, permanecendo em seu interior, a própria linguagem no seu sentido mais originário e, portanto, mais fundamental. Como com relação à técnica (cf. id. 2000, p. 54), também do perigo da linguagem surge uma ambiguidade: de um lado, a contínua perda, ao absoluto, da essência da linguagem - e, portanto, da essência do humano, de seu tópos - e, de outro, os lampejos de outro começo no torvelinho niilista da Gestell, diante da situação abissal do não-lugar que pode evidenciar, no abismo, em lampejos, a assunção de outro começo e a manifestação de uma Ereignis primordial (cf. id. 1989, p. 27).

Portanto, o que parece, na contemporaneidade técnica, próximo e familiar é, na verdade, não mais que a própria destituição da proximidade e da familiaridade do lugar. “Todo afastamento no tempo e no espaço está encolhendo. [...] O homem está superando as longitudes mais afastadas $[\ldots]$ e, no entanto, a supressão apressada de todo distanciamento não lhe traz proximidade.” (HEIDEGGER, 2001, p. 167, trad. nossa) É o tempo da indigência de que falava Hölderlin e ao qual, para Heidegger, pertence o pensamento de Nietzsche e a poesia de Rilke (cf. HEIDEGGER, 1977, p. 273-274). É para 
lidar com essa era de pretensa proximidade que servem os poetas na contemporaneidade: eles se arriscam no aberto (Offene), na exterioridade ontológica com relação à construção artificial de mundo da Gestell para, lá, constituir uma morada própria, ontológica e autêntica. Ao risco envolvido na exposição às intempéries do aberto do ser, o próprio Rilke evoca o desamparo do poeta, que, desalbergado, constitui uma morada (cf. ibid. p. 275276). Como um poeta em tempo indigente, Rilke é aquele que mais fundo vislumbra o abismo e, assim arriscado, prepara o resgate para o tempo vindouro, pois a reversão do desamparo ao aberto é também o aprofundamento de sua habitação no aberto, isto é, na linguagem (cf. ibid. p. 282).

Assim, o poeta e o pensador são convocados ao pastoreio (Hirten) da linguagem, ao pensamento meditativo que deixa ser o ente sem conformá-lo ao arbítrio do sujeito, em oposição direta com o pensamento calculador, representacional, instrumentalizante; em suma, ao habitar poético na linguagem. Esse habitar não é produto do querer humano, mas é um retorno que, como o poeta desamparado de Rilke, os mortais devem trilhar, um retorno à casa primordial da linguagem, um retorno do não-lugar rumo ao lugar e, portanto, à condição propícia para um outro começo da metafísica. A tarefa do pensamento que diz o ser, nesse sentido, é a de preparar, levar a cabo e reconduzir a uma situação que permita o advento do apelo do ser aos poetas, que transmitem a instauração de um mundo histórico pela linguagem. São aqueles que escutam, como clama Heráclito, o chamado do lógos, que retoma a revelação originária, essencial, na qual, como destinação primordial da linguagem, já sempre se habita e a qual há muito se esqueceu, de que hen pánta, "tudo é um", tudo se reúne sempre na unidade do mundo, de que a diferença mantém-se na unidade do lugar. É desse espanto que se erige um mundo, dele que se pertence ao "apelo que nos traz à fala" (HEIDEGGER, 2001, p. 190), dele que se constrói o mundo histórico situado na linguagem e dele que se convoca o humano ao pastoreio cuidadoso dos limites do inescrutável, do sagrado da ambiguidade própria da alétheia, da renúncia à expatriação da evasão do inescrutável divino na tentativa da vontade de controlar e perscrutar o mais íntimo do real e da espera comedida, no abandono, do apelo dos deuses e do aguardo pela nomeação originária da linguagem. 
Em síntese, não é, para Heidegger, a subjetividade que conforma a linguagem e, portanto, o lugar, mas é no interior mesmo da linguagem, na intimidade de sua casa, no mundo junto aos entes, na insistência extática na casa do ser que habita o humano, escutando, pertencendo e dialogando com a simplicidade mesma do mundo na unidade de uma medida linguísticoontológica - ou, simplesmente, topológica. Os mortais se encontram em meio ao apelo sem voz da linguagem, que instaura tempo e espaço na quietude da Ereignis. Ou seja, os mortais encontram-se nos limites de um tópos, sendo ele mesmo, linguagem, como acontecimento de mundo no apelo de reunião da quadratura. Dentro dos limites desse apelo, não se chega à linguagem como se chega a um ente que, ele mesmo, se vê já, desde sempre, no interior da linguagem, na proximidade da habitação do humano. A linguagem não é ente algum, e dela não se pode afirmar nada sem o risco de chegar às tautologias heideggerianas: a linguagem fala (die Sprache spricht), e fala em monólogo (am Monolog), cabendo ao humano escutar, sereno, a esse apelo e resguardar o velado do lugar da linguagem, habitando-o poeticamente, mesmo na fuga sem freios do niilismo da técnica.

\section{Referências bibliográficas}

AQUINO, Tomás de. Sobre a verdade. In: . Verdade e conhecimento. Trad. e org. de Luiz Jean Lauand e Mario Bruno Sproviero. São Paulo: Martins Fontes, 2002, p. 138-164.

ARISTÓTELES. Da interpretação. In: Órganon: Categorias, Da interpretação, Analíticos anteriores, Analíticos posteriores, Tópicos, Refutações sofísticas. 2. ed. Trad. de Edson Bini. Bauru: Edipro, 2010, p. 81-110.

CASANOVA, Marco A. Compreender Heidegger. $3^{\mathrm{a}}$ ed. Petrópolis: Vozes, 2012. (Série "Compreender")

CASEY, Edward S. The fate of place: a philosophical history. Berkeley; Los Angeles: University of California Press, 1998.

CARDOSO, Libâneo. Subjetividade e metafísica: a "Filosofia Primeira" em Descartes e Aristóteles. In: DESCARTES, René. Meditações sobre Filosofia Primeira. Trad., nota prévia e revisão de Fausto Castilho. Campinas: Unicamp, 2004. (Col. "Multilíngues de Filosofia Unicamp") 
FRANCK, Didier. Heidegger e o problema do espaço. Trad. de João Paz. Lisboa: Piaget, 1997.

HEIDEGGER, Martin. Beiträge zur Philosophie (vom Ereignis). v.65. Frankfurt am Main: Vittorio Klostermann, 1989. (Col. "Gesamtausgabe")

. Contribuições à filosofia (Do Acontecimento Apropriador). Trad. de Marco Antonio Casanova. Rio de Janeiro: Via Verita, 2015.

. Ensaios e conferências. $2^{\mathrm{a}}$ ed. Trad. de Emmanuel C. Leão, Gilvan $\overline{\text { Fogel e }}$ Márcia S. C. Schuback. Petrópolis: Vozes, 2001.

. Holzwege. v.5. Frankfurt am Main: Vittorio Klostermann, 1977. (Col. "Gesamtausgabe")

. Identität und Differenz. v.11. Frankfurt am Main: Vittorio Klostermann, 2006. (Col. "Gesamtausgabe")

. Seminare. v.15. Frankfurt am Main: Vittorio Klostermann, 1986. (Col. "Gesamtausgabe")

. Ser e tempo; Sein und Zeit. Ed. bilíngue. Trad., org., notas etc. de Fausto Castilho. Campinas: Unicamp; Petrópolis: Vozes, 2012. (Col. "Multilíngues de Filosofia Unicamp")

- Unterwegs zur Sprache. v.12. Frankfurt am Main: Vittorio Klostermann, 1985. (Col. "Gesamtausgabe")

1989.

. Überlieferte Sprache und technische Sprache. St. Gallen: Erker,

. Vorträge und Aufsätze. v.7. Frankfurt am Main: Vittorio Klostermann, 2000. (Col. "Gesamtausgabe")

. Wegmarken. v.9. Frankfurt am Main: Vittorio Klostermann, 1976. (Col. "Gesamtausgabe")

HÖLDERLIN, Friedrich. Poemas. Trad. e intro. de José Paulo Paes. São Paulo: Companhia das Letras, 1991.

KUSCH, Martin. Language as calculus versus language as universal medium: a study on Husserl, Heidegger and Gadamer. Dordrecht: Kluwer Academic Publishers, 1989.

MALPAS, Jeff. Heidegger's Topology: Being, Place, World. Cambridge: The MIT Press, 2006.

NOVALIS. "Monólogo". In:__. Pólen; fragmentos; diálogos, monólogo. Trad. de Rubens R. T. Filho. São Paulo: Iluminuras, 1988, pp. 195-196. 
PÁDUA, Lígia T.S. A "Topologia do Ser": lugar, espaço e linguagem no pensamento de Martin Heidegger. 2005. 300 f. Tese (Doutorado em Filosofia) - Departamento de Filosofia, Pontifícia Universidade Católica do Rio de Janeiro, Rio de Janeiro, 2005.

PITTA, Maurício F. Considerações preliminares sobre as noções de habitar e construir em Martin Heidegger e Peter Sloterdijk. Ekstasis: Revista de Hermenêutica e Fenomenologia, v.5, n.1, p. 61-71, 2016.

VON HUMBOLDT, Wilhelm. On language: the diversity of human language-structure and its influence on the mental development of mankind. Trad. de Peter Heath e introd. de Hans Aarsleff. Cambridge: Cambridge University Press, 1988. 